\title{
„Po co ten człowiek tam na górze?”. 0 politycznym wykorzystaniu przeżyć górskich
}

\section{DOI: $10.19195 / 2084-4107.12 .6$}

Gdy w 1874 roku po raz pierwszy ukazał się rocznik Alpejskiego Związku Trydentu (Società Alpina del Trentino, a od 1877 roku — Società degli Alpinisti Tridentini; S.A.T. $)^{1}$, wskazywano na opóźnienie, z jakim tenże związek z południowej, włoskojęzycznej części Tyrolu (Tyrol Włoski; dziś: Trydent) pojawił się na europejskiej scenie towarzystw alpejskich. W piśmie tym, będącym świadectwem różnic czasowych dotyczących rozwoju analogicznych procesów społecznych w Europie u schyłku XIX wieku, zaznacza się, że towarzystwa alpejskie zostały założone w Wielkiej Brytanii już w roku 1857, w Austrii w 1862, w Szwajcarii i we Włoszech w 1863, a w Niemczech w 1869. Tak więc powstanie większości stowarzyszeń przypada na lata 1855-1865, czyli na „złoty wiek alpinizmu” związany z pierwszymi wejściami na wysokie szczyty alpejskie. Natomiast założenie Società Alpina del Trentino 2 września 1872 roku w Madonna di Campiglio nastąpiło dużo później.

Prócz Londyńskiego Klubu Alpejskiego (Alpine Club), który w swoje szeregi przyjmował wyłącznie wybitnych alpinistów, wszystkie inne związki liczyły w tym czasie już pomiędzy 1200 a 1400 członków. W niemieckojęzycznym Tyrolu w 1871 roku istniały sekcje Niemieckiego i Austriackiego Związku Alpejskiego (DuÖAV) w Innsbrucku, Lienz, Bruneck, Bozen i Meran, liczące w sumie 313 członków - taki stan liczebny S.A.T. osiągnęła dopiero na początku lat osiemdziesiątych. Przedstawiciele trydenckiego mieszczaństwa, których przede wszystkim skupiała Società Alpina ${ }^{2}$, konstatowali nie tylko swoje zapóźnienie społeczno-kulturalne, lecz także znaczne deficyty w świadomości regionalnej. Ponadto uskarżali się na brak percepcji rodzimych gór. W odróżnieniu od kwitnącej eksploracji, podróży, opisów, naukowych opracowań i otwarcia turystycznego dotyczących sąsiednich krajów alpejskich, Trydent w istocie nadal pozostawał terra incognita. Tam zaś, gdzie mroki rozświetlały opisy podróży i wycieczek tudzież badania przyrodnicze, wypady w oddalone dotąd od cywilizacji tereny górskie wiązały się przeważnie z nazwiskami alpinistów i naukowców z zagranicy³.

${ }^{1}$ Prócz licznych raczej bezkrytycznych tudzież utrzymanych w uroczystym nastroju przyczynków autorów z kręgów bliskich związkowi dysponujemy historyczno-naukowymi monografiami: Nequirito 1988; Leoni 1989; Leoni 1990; Blanchon 1995.

2 Zob. Wedekind 2007.

3 Były to w pierwszym rzędzie osoby wywodzące się z wyższych warstw mieszczaństwa angielskiego, którym zasoby materialne oraz niezależność czasowa pozwalały na rozciągnięte w czasie i ekstrawaganckie przedsięwzięcia podróżnicze: John Ball (1818-1889), prezes Alpine Club, a w swoim czasie podsekretarz stanu w ministerstwie kolonialnym, był pierwszym z tych mieszczańskich grimpeurs w Trydencie. Zdobycie przez niego Monte Pelmo (1857) dało znak do rozpoczęcia eksploracji całego obszaru Dolomitów, która niebawem się rozpoczęła. Do tegoż eks- 
Konstytuującą rolę w powstaniu Trydenckiego Związku Alpejskiego odegrały więc nie sposoby rozumienia alpinizmu, jakie rozwinęły się w międzyczasie w Wielkiej Brytanii i na obszarze niemieckojęzycznym, tworząc rozbieżne profile $-\mathrm{z}$ jednej strony koncepcję opierającą się pierwotnie na zabawie i sporcie (symptomatyczne jest w tym kontekście The Playground of Europe Leslie Stephena), z drugiej zaś wyobrażenia raczej natury romantyczno-eskapistycznej nacechowane marzeniami o nieskażonej naturze. To nawet nie sam alpinizm tworzył właściwą podstawę ideologiczną stworzenia związku. Źródłem motywacji stała się raczej specyficzna postawa społeczno-psychologiczna charakteryzująca mieszczańsko-liberalną elitę kraju.

W owych czasach alpinizm uchodził za wysoce prestiżową emanację najbardziej postępowych społeczeństw mieszczańskich Europy. Wrażenie to wzmacniała nieodłącznie z nim związana kategoria niemalże obiektywnej ewaluacji i porównywalności osiągnięć alpinistycznych jednostek, które były zwykle postrzegane jako reprezentanci kolektywu etnicznego. Prócz zdobyczy natury sportowej, czy też związanych z technikami alpinistycznymi, z alpinizmem wiązało się również podejście naukowe angażujące rozmaite dyscypliny, w tym zakładające zdobywanie i zawłaszczenie terenów wysokogórskich. Osiągnięcia naukowe wykształconego mieszczaństwa, dokonywane w duchu pozytywistycznym, miały dla niego daleko idące znaczenie o wadze narodowej. W procesie naukowo-turystycznego udostępniania terenów leżących wysoko w Alpach widziano wszak w dobie kolonializmu ,zasadniczo [...] nic innego, jak specjalizację pewnego obejmującego całą Ziemię parcia ku badaniom i ekspansji, które po konsolidacji wewnętrznej budowy społeczeństwa zmierza ku rozciągnięciu swoich granic poza obszar po-

kluzywnego grona bywałych w świecie, kosmopolitycznych alpinistów brytyjskich, którzy dokonywali pionierskich wspinaczek w Trydencie pod koniec lat pięćdziesiątych XIX wieku, zaliczali się również Francis Fox Tuckett (1834-1913), Douglas William Freshfield (1845-1934), Richard Melvill Beachcroft (1846-1926), Edward Robson Whitwell (1843-1922) i Leslie Stephen (1832-1904). Tylko trochę później niż Anglicy do „zdobywania” i badania Alp Trydenckich dołączyli austriaccy i niemieccy alpiniści oraz naukowcy — jeszcze w ostatnich latach okresu przedmarcowego ukazały się Alpy niemieckie. Podręcznik dla podróżujących autorstwa Ernsta Adolpha Schaubacha (1800-1850), w którego czwartym tomie można bliżej poznać części Tyrolu leżące na południe od przełęczy Brenner. Jednak wypadom w tereny wysokogórskie początek dał dopiero pracownik wiedeńskiego urzędu pomiarowego Paul Grohmann (1838-1908), który od 1863 roku dokonywał licznych pierwszych wejść w Dolomitach, przede wszystkich w rejonie Ampezzo. Natomiast rozpoznanie i opisanie grupy Ortlera, Presanelli i Adamello wiąże się przede wszystkim z nazwiskiem pochodzącego z Czech podporucznika w służbie cesarsko-królewskiej Juliusa von Payera (1841-1915). Z kolei już w latach 1858 i 1860 urodzony na Śląsku Ferdinand Freiherr von Richthofen (1833-1905), który w 1856 roku jako pierwszy wspiął się na szczyty masywu Latemar, pracował nad geologicznymi i mineralogicznymi aspektami Dolomitów. Nacechowane wrażliwością przedstawienia natury i elementów ludowych autorstwa popularnego alpejskiego pisarza podróżniczego Heinricha Augusta Noëgo (1835-1896), jednego z popularyzatorów nowoczesnej turystyki, od początku lat siedemdziesiątych XIX wieku kierowały zaś na różne sposoby uwagę niemieckojęzycznych czytelników ku Trydentowi. 
lityczny, gospodarczy i społeczny"4. Jak to sumarycznie oceniono, powstanie towarzystw alpejskich „następuje w ścisłym związku z duchem czasu, po części także z prądami politycznymi ostatniego okresu i może zostać nazwane rozkwitem kultury nowożytnej"

Odbierane jako deficytarne społeczne mierzenie się z tym idealnym konglomeratem prowokowało wśród mieszczańskich elit Trydentu progresywne zaburzenie grupowego odczuwania wartości. Budziło nie tylko poczucie własnego zapóźnienia, raczej deklasacji, inferioryzacji, a - à la longue - frustracji. Znajdujemy je wciąż na nowo $\mathrm{w}$ świadectwach epoki tworzonych przez samych mieszczan i to daleko poza przełomem wieków ${ }^{6}$. Zagraniczna dominacja alpinistyczna interpretowana była jako akulturacja i inwazja. Ta w wysokim stopniu wrażliwa percepcja domniemanych lub realnych negatywnych skutków tegoż zjawiska wywodziła się ze środowiska, które z początku nie wykazywało szczególnego zainteresowania alpinizmem, teraz jednak szukało w tym obszarze samopotwierdzenia, biorąc za wzór europejskie środowiska mieszczańskie ${ }^{7}$. Horyzont doświadczeń politycznych większości założycieli S.A.T. można scharakteryzować poprzez antagonizm wynikający z aktywnego udziału w odwołującym się do risorgimento procesie jednoczenia Włoch po jednej stronie oraz pozbawiającej złudzeń ekskluzji z włoskiego państwa narodowego po drugiej.

Liberalny obóz prowincji za tym pilniejszą uważał internalizację ogólnonarodowej tożsamości wspólnotowej nacechowanej orientacją kolektywną, normami i zasadami działania nakierowanymi ostatecznie na irredentystyczne ideały związane z połączeniem z Królestwem Włoch. Jako że kręgi te nie miały dostępu do aparatu państwowego, a tym samym nie dysponowały klasycznymi organami socjalizacji (instytucje oświaty, wojsko), musiały wypracować zastępcze środki służące społecznemu osadzeniu narodowości. I to poprzez daleki od polityki i związany z „czasem wolnym” obszar alpinizmu dokonano próby politycznej koncentracji sił i dyfuzji ideologii. $Z$ tej instrumentalizacji wywodzi się panujący od początku w S.A.T., noszący zalążek konfliktu, element nacjonalistyczny, który we wcześniej powstałych związkach alpejskich mocniej zaznaczył się dopiero w późniejszych latach ${ }^{8}$. Oficjalne cele związku zdominowane były — w mniej

4 Steinitzer 1914, s. 67.

5 Schiestl 1873, s. 307.

6 Zob. np. Riunione 1874, s. 20-21; Stenico 1905, s. 77-78; Lorenzoni 1922, s. 60.

${ }^{7}$ Symboliczny wyraz dążenia te znalazły w pierwszym włoskim zdobyciu najwyższego szczytu Alp Trydenckich — Presanella — z okazji pierwszego zebrania członków S.A.T. w 1873 roku. Podczas gdy w wypadku Austriackiego Związku Alpejskiego to aktywni turyści wysokogórscy, tacy jak Paul Grohmann, Edmund von Mojsisovics (1839-1907), Guido Freiherr von Sommaruga czy też Anton von Ruthner (1817-1897), dali impuls do założenia związku, to ani inicjatorów założenia S.A.T., ani wielu jego wczesnych członków nie można nazwać wytrawnymi alpinistami. Większość z nich występowała raczej jako regionalni aktywiści włoskiego ruchu narodowego, w szczególności ochotnicy z wojny roku 1866.

${ }^{8}$ Godne uwagi wydaje się w tym kontekście pismo Centralnej Komisji Niemieckiego i Austriackiego Związku Alpejskiego z 1886 roku, skierowane do sekcji Nonsberg, wedle którego „[n]a 
lub bardziej jawny i symboliczny sposób — przez maksymy irredentystyczne 9 . Założenie Trydenckiego Związku Alpejskiego należy więc umiejscowić ideowo nie tyle w europejskim ruchu alpinistycznym, ile we włoskim ruchu narodowym.

Tak też tradycyjny, pierwotnie w ogóle panujący w alpinizmie, motyw wspierania badań i prezentacji danego alpejskiego obszaru pracy, który został zapisany w statutach licznych towarzystw alpejskich jako cel związkowy, był w Trydencie od początku mocniej obciążony politycznie. Jako wiodący cel związek wyznaczył sobie opis ojczystego świata gór ${ }^{10}$. W tym kontekście S.A.T. zachęcała do badania terenu i uprzystępniania go w duchu pozytywistycznym szerokim kręgom turystów, co miało stanowić konkurencję dla zaawansowanych już na tym obszarze działań towarzystw i badaczy z zagranicy. Aktywności takie miały obejmować zarówno badania geograficzne i historyczne, lingwistyczno-toponomastyczne, etnograficzne oraz przyrodnicze, jak i skartografowanie i alpinistyczno-turystyczny opis regionu ${ }^{11}$. Własne normy i wartości trydenckie mieszczaństwo ukazywało jako powszechnie obowiązujące w całym społeczeństwie ${ }^{12}$. Praktyczne wskazówki dotyczące prywatnych obserwacji i zbiorów przyrodniczych, nawoływanie do opisywania tras wycieczek czy do zbieractwa służyły popularyzacji przedsięwzięć naukowych. Badanie Alp uzyskało w specyficznym kontekście regionalnym funkcję związaną z upewnieniem się o własnej wartości. Jednocześnie oświecone mieszczaństwo zoperacjonalizowało „kulturowe zawłaszczenie"13, objęcie w materialne posiadanie i muzealne uświadomienie ojczyzny. Rocznik S.A.T., będący publicystycznym medium dla po części ludowej, po części naukowej przyrodniczo-regionalistycznej dyfuzji wiedzy, w latach 1879-1880 wyznawał wszelako, że chodzi w nim nie tyle o naukową kognicję i oryginalność, ile o aspekty grupowej organizacji emocji ${ }^{14}$. Również sport górski i wędrówki alpejskie poprzez indywidualne „przeżywanie ojczyzny” odgrywały swoją rolę w kontekście tego kolektywnego procesu powstawania świadomości i integracji ${ }^{15}$. Zakumulowany

pytanie, czy również Włosi mogą wstępować do Związku [...] należy odpowiedzieć zdecydowanie twierdząco”. Trzy lata później donoszono Centralnej Komisji, że „wielu członków, szczególnie z gmin włoskich, wystąpiło z Sekcji [...]. Przyczyną jest tegoroczne zebranie włoskiego Związku Szkolnego Pro Patria, które miało miejsce w Rumo. W czasie tego zebrania zaatakowano włoskich członków Związku Alpejskiego i powiedziano im, że Włosi nie powinni czynić wspólnoty z Niemcami; Skoro chcą akurat mieć Związek Alpejski, to są też włoskie" - Società degli alpinisti tridentini - Archivio storico (dalej: S.A.T.-ASt.), zbiory „DuÖAV-Sektion Nonsberg”, Centralna Komisja Niemieckiego i Austriackiego Związku Alpejskiego do Sekcji Nonsberg ([do] Franza Xavera Mitterera [w] Proveis), 29.11.1886; oraz Sekcja Nonsberg do Komisji Centralnej, Proveis, 13.12.1889.

9 Zob. Zippel 1912, s. 29.

10 Zob. S.A.T.-Ast., segregator 1, fascykuł 137: Riunione generale soci S.A.T., Arco, 8.05.1874 (przemowa Marchetti). Po niemiecku: Mitgliederversammlung der S.A.T. [Zgromadzenie ogólne członków S.A.T.].

11 Por. Vadagnini 1965.

12 Zob. Istituzione 1874, s. 6; Assemblea 1879/1880, s. 13; Sessione 1875, s. 6-7.

13 Leoni 1990, s. 69.

14 Prefazione 1879/1880, s. VII.

15 Zob. Alpi 1908, s. 2. 
zapas kolektywnej wiedzy i emocji miał doprowadzić do zakorzenienia wspólnych wzorców rozumienia i interpretacji, systemu wyobrażeń, grupowej „kosmologii”. Za socjologiem Ervingiem Goffmanem można tu mówić o tych ,pierwotnych ramach społecznych" ewokujących wspólne zorientowanie działań ${ }^{16}$.

Wysoki poziom emocji związany z przeżyciami górskimi ma źródło w doznaniach estetycznych odnoszących się do tego, co wzniosłe w metafizycznym objawieniu oraz w uczuciu wyjątkowej niecodzienności, w której siły przyrody i własna natura tworzą jedyne determinanty. Już pierwszy szturm na szczyty alpejskie w żadnym razie nie służył wyłącznie poznaniu marginalnych dotąd przestrzeni geograficznych, lecz według swoich protagonistów wiązał się równie mocno z voyage intérieur i z eksploracją światów wewnętrznych. Walkę z naturą i pełne niebezpieczeństw zdobywanie góry alpinista przeżywał w pięknej scenerii krajobrazowej z dala od miejskiego towarzystwa; ten temporarny prymitywizm pozostawał jednak wciąż powiązany z centralnymi kategoriami mieszczańskich wzorców społecznych i wzorów cnót mieszczańskich. Co więcej, naznaczony ryzykiem i eksponujący siłę jednostki alpinizm zdawał się przeniesioną w świat czasu wolnego analogią indywidualistycznego projektu życia społeczeństwa mieszczańskiego, wręcz egzemplifikacją jego wartości i norm. To w nim dostrzegano odpowiednik mieszczańsko-antyarystokratycznej formy życia, wedle której nie miało ono być próżniactwem, a zobowiązaniem - obowiązkiem pracy i osiągnięć, indywidualnego doskonalenia, maksymalnego rozwoju zasobów duchowych, moralnych i fizycznych — dla pożytku zarówno osobistego, jak i publicznego ${ }^{17}$.

Idee postępu i cywilizacji manifestowały się nie tylko w zdobyciu i zawłaszczeniu leżących z dala od cywilizacji rejonów wysoko w Alpach, lecz także w przyjęciu wartości i zorientowaniu na zachowania zaczerpnięte $\mathrm{z}$ alpinizmu. Trafność mieszczańskiej zasady nakierowania działań na osiągnięcia można było w sposób dobitny ukazać w górach - wyczyn lub wysiłek fizyczny, u którego podstaw leżała własna autonomiczna inicjatywa, otrzymywały kompensację w postaci silnie nacechowanych emocjonalnie przeżyć związanych ze zdobyciem szczytu. Ściśle wiązała się z tym ta euforia, która miała uwalniać uczucie indywidualnej samorealizacji w ramach przyjętego normatywnego systemu wartości; mówiono o „uroku przezwyciężonych trudów i niebezpieczeństw” oraz o „subiektywnym zadowoleniu z własnego wyczynu"18. Takie elementy, jak walka z uciążliwościami czy z przeszkodami stawianymi przez przyrodę, przezwyciężanie niebezpieczeństw wysokogórskich oraz samodzielne zarządzanie ryzykiem, dawały się subtelnie funkcjonalizować w duchu mieszczańskiej dyscypliny społecznej. Czyż kapitalizm nie uchodził — zwłaszcza wedle teorii darwinizmu społecznego — za egzystencjalną walkę o przetrwanie, która obok sukcesu ekonomicznego kryła w sobie stałe zagrożenie jednostki upadkiem socjalnym? Czy przedsiębiorca nie był wciąż konfrontowany z ryzykiem ekonomicznym? I czy w ogóle to nie wyobrażenia do-

16 Goffman 1977, s. 37, 274.

17 Lorenzoni 1906, s. 144, 148.

18 Richter 1891, s. 35. 
tyczące woli i podejmowania ryzyka przez jednostki będące podmiotami w procesach historycznych, a polityki jako czynu i prymatu jednostki nacechowały tak silnie spersonifikowany ówczesny obraz historii, każąc tu Giuseppe Garibaldiemu (1807-1882) ${ }^{19}$, a tam Otto von Bismarckowi (1815-1898) stać się viri exempli liberalnego ideału osobowości? Generacja założycieli Trydenckiego Związku Alpejskiego żyła tym ideałem narodowego obowiązku jednostki.

W tym kontekście alpinizmowi zostały przypisane szczególne wartości edukacyjne odnoszące się do morale narodowego. Wychowawczych pożytków płynących ze wspinaczki upatrywano we wzmocnieniu indywidualnej siły woli i gotowości do podejmowania ryzyka ${ }^{20}$. Alpinizm zalecany był więc nie tylko w swoim ogólnohigienicznym aspekcie, lecz przede wszystkim jako trening fizyczny i męskie wychowanie, pole do nauki dyscypliny, posłuszeństwa, ofiarności i heroizmu, a także jako „szkoła charakteru”, która w dużym stopniu miała na celu wdrażanie mieszczańskiego ideału wychowania odnoszącego się do indywidualnej kontroli emocji oraz sublimacji subiektywnych emocji i pasji w konstruktywną energię. Ten model zachowania, nastawiony w sposób oczywisty na wzorce militarne, zakładał pełen rozdział umysłu od emocji, a wręcz ich opanowanie przez umysł ${ }^{21}$. Naturalnie taki stan rzeczy stał w opozycji do narodowej organizacji emocji, którą miał wytworzyć alpinizm.

Przeżycie górskie jako egzemplifikacja zdeterminowanego nacjonalnie katalogu wartości i cnót, alpinizm jako napęd poglądów narodowych, jako wychowanie $\mathrm{w}$ duchu obronno-heroicznego idealizmu - to toposy rozpowszechnione w historii alpinizmu XIX i XX wieku, które przyswoiła sobie większość towarzystw alpejskich. Jednak idealizowany w kontekście narodowym alpinizm (jak i postępująca za tym jego militaryzacja) pojawił się w S.A.T. bardzo wcześnie. W swej leksyce alpinizm jawi się niemal jako synonim narodowego ideału - italianità, a i zdobywaniu czy udostępnianiu terenów wysokogórskich bardzo wcześnie zaczęło towarzyszyć ich narodowe zajmowanie. Świat gór utracił swój charakter rzeczy w sposób święty uniwersalnej, który przypisywano mu we wczesnej fazie alpinizmu, i został wystylizowany na narodową przestrzeń sakralną. Indywidualnym osiągnięciom wspinaczkowym, a także budowie schronisk i dróg zaczęto w coraz większym stopniu przypisywać irracjonalny aspekt „,narodowo-alpinistycznego objęcia w posiadanie" kraju. Monumentalna sceneria wysokogórska została ujęta w topografię miejsc znaczących dla narodowej tożsamości - po części poprzez konotatywne przypisania, które kompensowały brak konkretnie poddającego się percepcji programu ikonograficznego, po części poprzez programową toponimię schronisk alpejskich i nowo poznanych szczytów górskich ${ }^{22}$ lub też w formie sta-

19 Carlo Tivaroni uczcił Garibaldiego, w swojej wielkiej historii Risorgimento nazywając go „Zbawicielem” i „Nazareńczykiem” — Tivaroni 1897, s. 482-483.

20 Bolognini 1874, s. 201, 231-233.

21 Brocherel 1898, s. 38.

22 Ideową łączność Trydentu z włoskim państwem narodowym miały wzmacniać patronaty państwa włoskiego roztaczane nad poszczególnymi schroniskami górskimi. Jakby naprzeciw im 
wiania pomników oraz rytualnych symbolicznych, a niekiedy w otwarty sposób nacjonalistycznych demonstracji w rejonie szczytowym ${ }^{23}$. Wędrówki na szczyty stały się politycznymi pielgrzymkami ${ }^{24}$, pierwsze wejścia zaś czynem narodowym. Wykazanie się osiągnięciami alpinistycznymi równoważnymi do osiągnięć zagranicznych wspinaczy miało rangę narodowego ratowania honoru. Ten system znaków i zachowań zyskał w kontekście narodowego współzawodnictwa związków alpinistycznych oraz upolitycznienia turystyki wybitne znaczenie symboliczne.

Wraz z młodą generacją dostęp do alpinizmu zyskały wkrótce motywy krytyki cywilizacji, które długofalowy wpływ zawdzięczają Arturowi Schopenhauerowi (1788-1860), a szczególnie Fryderykowi Nietzschemu (1844-1900) i Gabriele’owi D’Annunziemu (1863-1938). Były one echem słabnącej siły integracyjnej liberalizmu i dawały mocny wyraz sceptycyzmowi wobec racjonalnego, związanego z wiarą w postęp mieszczańskiego procesu cywilizacyjnego. Dyskusję tę na którą wpływ miał przedstawiciel awangardy nowego prądu polegającego na wspinaniu się bez przewodnika, Eugen Guido Lammer (1863-1945) - po przełomie wieków spopularyzowali w środowisku alpinistycznym przede wszystkim ekonomista, prawnik i wykładowca z Innsbrucka Giovanni Lorenzoni (1873-1944) oraz Mario Scotoni (1883-1958), swego czasu jeszcze słuchacz na Uniwersytecie w Innsbrucku. Ostro zanegowano wówczas intelektualizm, ekonomiczny utylitaryzm, wyzucie z pasji i emocji, hedonistyczny letarg i dekadencję, słabość i przeciętniactwo jako presumptywne skutki mieszczańsko-kapitalistycznego porządku społecznego i gospodarczego. Postulowano natomiast witalność i siłę woli, namiętność i umiejętność cierpienia, heroizm, wielkość i ideały ${ }^{25}$. Ruch, spontaniczność i wolę działania przeciwstawiono stagnacji, siłę i męskość zaś — upadłemu humanizmowi i degeneracji. Idealizowano i estetyzowano niebezpieczeństwo, a nawet agonię, które miały uwalniać instynkty i emocje, a także wytrwałą, zaprawioną w boju mężną fizyczność, której zadaniem jest zmierzyć się z tymi niebezpieczeń-

stały ze strony niemieckiej nowe toponimy lub też substytuty, które po części otrzymały nazwy od członków domu habsburskiego, po części zaś od swoich sekcji: „Bamberger Hütte”, „Berliner Hütte”, „Bremer Hütte”. W spornej kwestii poruszającej „W wybitny sposób nasze uczucia oraz odczucia lojalności i patriotyzmu", a dotyczącej nazwania jednego z trydenckich szczytów imieniem austriackiego monarchy, Austriacki Klub Turystyczny (Österreichischer Touristen-Club) i DuÖAV stały na stanowisku, że jest ,zupełnie wykluczone, aby nazywać imieniem naszego Cesarza szczyt, który znaczeniem, wysokością i prestiżem ustępuje szczytowi noszącemu niestety imię człowieka [włoskiego alpinisty Alberto de Falknera - M.W.], który [...] z całą pewnością w najmniejszym stopniu nie był przychylny Austrii; jednak szczyt, który wybierzemy, nie może również ustępować tym, które noszą imię kogoś takiego kim był, jakkolwiek zasłużony dla Włoch, minister [Quintino] Sella" - Archivo di Stato di Trento (dalej: AST), Sezione di Luogotenenza di Trento, Presidiali 1868-1896 (dalej: Sez. di Luogoten. di Trento, Pres.), 1894, segregator 148: Austriacki Klub Turystyczny do Zarządu S.A.T., Wiedeń, 4.08.1894.

${ }^{23}$ O tym zob. Bezzi 1962.

24 Zob. Sighele 1904, s. 3; Inaugurazione 1908, s. 11.

25 Zob. Lorenzoni 1911, s. 9-10; Lammer 1907, s. 47. 
stwami $^{26}$. W rozmaitych artykułach pisma związkowego, ale i w publicznych wykładach Lorenzoni podejmował orędownictwo Nietzschego za „niebezpiecznym”, intensywnym pod względem emocji i napięcia, heroicznym życiem. Sport górski uprawiany w formie wspinaczki bez przewodnika zdawał mu się środkiem wychowawczym właściwym do tych fizycznych i moralnych ideałów kultury przedkapitalistyczno-arystokratycznej. Tak jak u Nietzschego i D'Annunzia, zamierzony proces formowania był tu sprzężony z — występującą również w rozprawach Scipia Sighelego (1868-1913) dotyczących psychologii mas — ideą elity ${ }^{27}$. Tak jak Zaratustra wspina się na góry wysokie, aby ozdrowieć, aby zanieść „,popiół [cywilizacji — M.W.] w góry”, a po swej przemianie „ogień [nowych ideałów M.W.] w doliny", tak nowe pokolenie alpinistów ma zostać wyzwolone z cierpień cywilizacji.

Wraz z nadejściem ,,alpinizmu niebezpieczeństw” w sporcie górskim dokonało się również ,przewartościowanie wszystkich wartości”, o którym mówił Nietzsche i inni przedstawiciele krytyki cywilizacji. Już nie przeżywanie piękna przyrody na wierzchołku udostępnianym w międzyczasie coraz szerszej publiczności turystów wysokogórskich dzięki przewodnikom górskim i ścieżkom, lecz śmiałe indywidualne osiągnięcia alpinistyczne i podejmowanie wyzwań okazywały się teraz ekskluzywnym elementem obrazu świata. Nie szczyt, lecz droga na niego stały się właściwym celem przedsięwzięć wspinaczkowych. Przedstawicielom tego nowego rodzaju alpinizmu nie chodziło już o obyczajowe podniesienie człowieka poprzez ukazanie tego, co wysublimowane, ale o uformowanie całkiem nowego człowieka, przezwyciężającego samego siebie herosa, nietzscheańskiego ,nadczłowieka” czy superuomo D’Annunzia. W swej koncepcji „filozofii heroicznej” Nietzsche definiuje heroizm jako ,postawę człowieka, który dąży do celu, na którego osiągnięcie nie może liczyć" 28 . Również Lorenzoni, chcący formować nowy typ człowieka w górach, mówi o dążeniu do przekroczenia granic normalności ku temu, co pozornie nieosiągalne. Jego zdaniem jest to instynktowny ludzki wzorzec działania, który zostanie wywołany przez sport górski tam, gdzie człowiek przezwycięży sam siebie, gdzie woluntarystycznie wyzwie naturę wraz z jej przeszkodami i niebezpieczeństwami i w końcu nad nią zatryumfuje — jak określał to Nietzsche, „Wielki człowiek jako rywal wielkiej natury”29.

Tak rozumiany alpinizm stał się ,gimnastyką woli"30. W sposób ewidentny to Zarathustra określa u Lorenzoniego ocenę historii zdobywczej i pionierskich osiągnięć w dziedzinie alpinizmu jako ekspresję „woli mocy”, która ze względu na samą siebie jawi się wyniesiona do poziomu niewrażliwości na ból, męczeństwa i samopoświęcenia. Niewiele później futurystyczne manifesty tego rodzaju wyobrażeń zyskały jeszcze bardziej radykalną polityczną formułę: „Wysławiamy

\footnotetext{
26 Zob. Lorenzoni 1904, s. 6; Scotoni 1905, s. 54.

27 Sighele 1897, passim.

28 Nietzsche [b.r.w.], s. 366.

29 Nietzsche [b.r.w.], s. 389.

30 Nietzsche [b.r.w.], s. 376.
} 
umiłowanie niebezpieczeństw i władzy, patriotyzmu i wojny jako jedynej higieny świata"31. U Italo Lunelliego (1891-1960), późniejszego ochotnika w armii włoskiej, a potem członka partii faszystowskiej, alpinizm staje się wreszcie w 1913 roku - widocznie zerotyzowaną - formą zastępczą wojny ${ }^{32}$. Dyskusję tę, której immanentny polityczny charakter został wyeksplikowany przez jej uczestników, cechowała ambiwalencja. Jej uczestnicy byli przekonani o istotnej i obowiązującej roli ogólnospołecznej propagowanych wzorców zachowań. Chodziło im o przesunięcie wartości i norm ze sfery instancji socjalizacji związanych z ,czasem wolnym" do kontekstów społecznych i politycznych.

W sferze retorycznej oba obszary łączyły, po części metaforyczne, analogie heroiczna walka z mocarną przyrodą wysokich gór musiała być rozumiana jako paralela do walki z przeważającym wielokrotnie przeciwnikiem etnicznym; przyswojone wzorce cnót zdawały się przy tym zapewniać ekstremalną indywidualną gotowość do ponoszenia ofiar w imię ideałów własnej grupy. Krytyka cywilizacji okresu fin de siècle została przeniesiona do sfery politycznej i wintegrowana w ideologię nacjonalizmu.

Partnerstwo liny w górach, rozumiane jako lojalnościowy związek rozkazującego i podporządkowującego się rozkazom, odpowiadało w sposób emblematyczny własnej grupie etnicznej i jej postulowanej wewnętrznej konstytucji — zdawało się, że w obu przypadkach zewnętrzne niebezpieczeństwa i zagrożenia wymagają spójności grupy i jej intencjonalnej tożsamości. Jednocześnie następuje projekcja na ten obraz dyskusji „,mas”, która naznaczyła przełom wieku — fobia dotycząca agresji i społecznej destrukcji zagrażającej ze strony mas oraz poszukiwanie środków jej okiełznania. Nietzsche z jednej strony odwoływał się w zagmatwany sposób do hierarchii mas, a z drugiej — do pokonującego je ,wyższego gatunku człowieka". Sighele natomiast uważał, że ten budzący głęboki wstręt despotyzm mas, który wywoływał u niego „lęk przed uduszeniem” i „śmiertelny dreszcz”, można zmodyfikować jeszcze tylko w sensie jakościowym. Jego koncepcja polegała na dyscyplinowaniu i intencjonalnej uniformizacji mas; chodziło mu o uformowanie kolektywnej świadomości tożsamościowej poprzez ideologiczną penetrację, poprzez dyfuzję idei narodowej ${ }^{33}$. Myśl ta w żadnym razie nie była nowa - we Włoszech w 1878 roku posługiwał się nią Francesco de Sanctis (1817-1883) ${ }^{34}$, a w Niemczech reprezentował ją na przykład historyk Johann Gustav Droysen

31 We włoskojęzycznym oryginale: „Noi [...] glorifichiamo [...] l'amore del pericolo e della violenza, il patriottismo e la guerra, sola igiene del mondo", De Maria 1981, s. 161.

32 Lunelli 1913, s. 2.

33 Zob. mowa Sighele „Irredentismo e nazionalismo” na Kongresie Nacjonalistów w 1910 roku we Florencji (Museo Storico, Trento, Archivio „A.F. (Scipio Sighele)”, segregator 2; zob. też Sighele 1922, s. 6.

34 Francesco de Sanctis w swoich przemyśleniach o samoświadomości filozoficznej, etycznych i kulturowych podwalinach zjednoczonych Włoch, a zwłaszcza w swojej koncepcji narodowo-wychowawczej, wychodził z opozycji pomiędzy wiekiem XVIII i XIX, którą dostrzegał w opisie powiązanych z czasem antytetycznych aspiracji do „wolności” tudzież „granicy” (limite) — De Sanctis 1970, s. 170 n. 
(1808-1884) już na początku lat pięćdziesiątych XIX wieku ${ }^{35}$. Pierwotny jest wobec tego psychologizm Sighelego w jego analizie zachowania mas ${ }^{36}$.

Jednocześnie wysublimowana płaszczyzna emocji, psychical height przeżyć na szczycie, pod wpływem instancji socjalizacyjnych „,czasu wolnego” została zawłaszczona narodowo. Przejście ze sfery realnej do sfery imaginacji, wywołane przemożnym afektowanym postrzeganiem krajobrazu, zostało nakierowane politycznie - wyobrażenie zniwelowania granic jednostki włączającej się w uniwersum przedstawione zostało teraz, w nawiązaniu do idei Johanna Gottlieba Fichtego (1762-1814) i Vincenza Giobertiego (1801-1852), jako wyimaginowana fuzja jednostki z wyobrażoną wspólnotą narodu. Tam, gdzie romantyczne wyobrażenia poety Giacomo Leopardiego (1798-1837) rozpływały się jeszcze w wizjach nicości i nieskończoności, pojawił się teraz polityczny ideał tego, co dotyczy kolektywnej wyobraźni ${ }^{37}$. Tam zaś, gdzie później Nietzsche, krytykując Ratio, wzywał w Woli mocy, aby „odrzucić domniemane indywiduum”, „odczuwać kosmicznie poza »mną« i »tobą «"38, tam reinterpretacja krytyki cywilizacji doprowadziła w końcu do wyobrażenia o rozpłynięciu się jednostki w organicznym ciele naro$\mathrm{du}$, a wręcz do podporządkowania się jednostki ideałowi ${ }^{39}$.

Trydencki Związek Alpejski w ostatnich latach przed wybuchem wojny coraz bardziej tęsknił za zbrojną konfrontacją Włoch z Habsburgami. W kryptycznych aluzjach pojawiających się w pismach związkowych już w 1912 roku tych alpinistów ze związku, którzy poprzez paramilitarne wykształcenie byli przygotowani na wojnę, widziano w roli przyszłych obrońców ,ideału”. Przywódcy związkowi wystosowali także w sierpniu 1914 roku petycję do króla Wiktora Emanuela III (1869-1947), w której prosili w imieniu ludności Trydentu o interwencję militarną Włoch skierowaną przeciwko Austrii. Niemało eksponentów kierownictwa związku udało się od sierpnia 1914 roku do Włoch, aby wspierać tam kampanię wojenną oraz późniejsze werbowanie ochotników do wojska. Właśnie z tych szeregów kształtował się nieco później także krąg trydenckich faszystów.

Natomiast wraz z przystąpieniem Włoch do wojny w 1915 roku Niemiecki i Austriacki Związek Alpejski poczuły się wreszcie uwolnione od zmory zagrożenia; „dzień wypowiedzenia wojny przez Włochy” święciły jako „dzień uwolnienia od trwającego dziesięciolecia zakłamania i obłudy”40 dotychczasowego sojusznika włoskiego. Jednakowoż w ostatnim roku wojny światowej, gdy niemieckim publicystom związkowym przeszedł wprawdzie zachwyt wojną, lecz nie patetyczny ton, w ukazującym się co miesiąc biuletynie Niemieckiego i Austriackiego Związku Alpejskiego można było przeczytać:

\footnotetext{
35 Hardtwig 1990, s. 144-145.

${ }^{36}$ König 1992, s. 143 n.

37 Zob. Sighele 1904, s. 3.

38 Zob. Nietzsche [b.r.w.], s. 384; Lorenzoni 1911, s. 8.

39 Zob. Lorenzoni 1911, s. 16.

40 Edlinger 1915, s. 151.
} 
Jak straszliwe wrażenie robi na nas właśnie tutaj w górach taki obraz bezimiennej nędzy [wojennej - M.W.]. Tysiąckrotnie większe zdaje się nam być okrucieństwo zniszczenia. Ruiny wsi krzyczą do niebios, kikuty drzew łkają jak okaleczeni ludzie. Tryskające z rozoranych stoków wody toczą krew. Łąki leżą szare i martwe, jak gdyby nie miały się nigdy, nigdy zazielenić. — Tak jest [sic!], bo jest to nasza ojczyzna, bo są to miejsca najszczęśliwszych godzin, których błogie wspomnienie chowamy głęboko w sercu i które teraz w okrutny sposób zniszczyła wojna. To właśnie to każe nam po trzykroć okrutniej odczuwać cierpienie. Czujemy, że wojna nigdzie nie może być straszniejsza niż tu w naszych górach, krainie, która skrywała boski pokój i wielką spokojność ${ }^{41}$.

Godną publikacji wrażliwością na masowo wywołane przez wojnę ludzkie cierpienie pisma związkowe nie wykazały się jednak nawet po zniesieniu cenzury prasowej. Coś więcej niż tylko wytrwały patriotyzm było w tym, że Związku Alpejskiego nawet po zakończeniu wojny nie gorszył w żaden sposób fakt, iż w ,jego" górach — na Col di Lana czy na Monte Pasubio - wykrwawiły się całe regimenty, zarówno włoskie, jak i austriackie czy niemieckie (wśród nich nierzadko liczni „towarzysze związkowi”), w bezsensownej walce często o skrawek ziemi szerokości dłoni.

Wojna zradykalizowała po raz kolejny istniejące już przypisania przestrzeni - stworzyła nowe narracje o Alpach, wystylizowała tutejsze góry na „niemiecką świętość”, inne — na „ołtarz Włoch”. Na tle politycznie instrumentalizowanej żałoby i kultu zmarłych w ten teraz już politycznie zsakralizowany krajobraz oraz w kolektywną świadomość nowych narodowo-pielgrzymkowych rzesz turystów, odwiedzających pola bitewne i pomniki wojenne, utracone i anektowane tereny, wraz z monumentalną architektoniczną kulturą pamięci wpisywały się a to nawoływania do rewanżu, a to pośmiertne usprawiedliwianie udziału w wojnie. Jakkolwiek podróżowanie po Wschodnich Alpach w okresie międzywojennym w żadnym razie nie stało wyłącznie pod znakiem politycznej retoryki i agitacji — tym, co - także poza tradycyjnymi i nowymi formami wypoczynku i rozrywki (jak rozwijające się narciarstwo) - ciągnęło wielu znowu w góry, było wewnętrzne przezwyciężenie przeżyć wojennych poprzez spotkanie z naturą.

Z języka niemieckiego przetożyła Monika Witt

41 Schmidkunz 1918, s. 62; zob. też Menger 1919, s. 187. 